\title{
Some sociological Bases of transnational Practices in Italy
}

Bases sociologiques des pratiques transnationales en Italie

Algunas raíces sociológicas de prácticas transnacionales en Italia

\section{Michael Eve}

\section{(2) OpenEdition}

Electronic version

URL: https://journals.openedition.org/remi/4522

DOI: 10.4000/remi.4522

ISSN: $1777-5418$

\section{Publisher}

Université de Poitiers

\section{Printed version}

Date of publication: 1 November 2008

Number of pages: $67-90$

ISBN: 978-2-911627-49-0

ISSN: 0765-0752

\section{Electronic reference}

Michael Eve, "Some sociological Bases of transnational Practices in Italy", Revue européenne des migrations internationales [Online], vol. 24 - $n^{\circ} 2$ | 2008, Online since 01 November 2011, connection on 15 April 2022. URL: http://journals.openedition.org/remi/4522 ; DOI: https://doi.org/10.4000/remi. 4522 


\title{
Some sociological Bases of transnational Practices in Italy
}

\author{
Michael EVE*
}

\section{ONE PHENOMENON OR SEVERAL?}

As many writers have noted (among others, Portes, Guarnizo and Landolt, 1999, Vertovec, 1999; Faist, 1999; Itzigsohn et al., 1999; Kistivo, 2001), the term transnationalism has been used to describe very different situations. On the one hand, we have, for example, classic and contemporary examples of "diasporas" with a strong sense of being "communities" - where people identify themselves clearly as members of a social unit dispersed over the world in various countries, and where shifting to another node of the community in another part of the world may be a possibility people are clearly aware of. Sense of belonging to this transnational community may be sustained by all the usual mechanisms creating an imagined community (language, religious specificity, myths regarding a common origin, etc.), but also by frequent material exchanges, regular meetings on festive and other occasions, mutual aid, occupational careers, business connections, inter-marriage; and these patterns may last for very long periods, of a century or more. On the other hand, discussions of transnationalism may also cite phenomena, which are present in the experience of nearly all international migrants (and even that of many internal migrants moving within a single state). For example, migrants go back 'home' for holidays (sometimes long holidays), maintain numerous ties with kin in other countries, send remittances at least in some circumstances (and these may be important for the home area's economy), watch television programmes broadcast by their 'country of origin', invent new cultural forms combining elements from two or more countries (nearly all the interviewees of our research in Italy combined elements of Moroccan/Romanian with elements of Italian food), continue to use their first language, perhaps build a house back home, and so on. Some scholars (cf. among many others, Portes, Guarnizo and

* Dipartimento di Ricerca Sociale, Università del Piemonte Orientale, via Cavour, 84, 15100 Alessandria, Italy, michael.eve@sp.unipmn.it 
Landolt, 1999) try to exclude these weaker forms; others continue to cite them as evidence of transnationalism, either justifying the choice explicitly (e.g. Itzigsohn et al., 1999) or implicitly, by applying the adjective transnational in texts and titles of books and articles.

In any case, it does seem necessary to distinguish between the various practices, which can be described as "transnational" in order to avoid confusion between phenomena, which have very different implications, and different dynamics. Comparison between them also seems useful in order to understand why in some places and times certain kinds of ties are maintained across frontiers, whereas in others they are not. In these comparative notes on transnational practices among migrants in Italy, I will therefore also ask why more developed transnational phenomena are often absent. To understand transnationalism, negative cases seem no less important than those, which show more full-blown manifestations of people living genuinely in two or more countries; and comparisons between negative and positive cases would seem fruitful. After all, if we reject "methodological nationalism" (Glick Schiller at al., 1992, 1995) and the notion that people's social relations inevitably tend to conform to national boundaries, we cannot see as merely natural and not requiring explanation the fact that some people maintain only highly selected ties with their country of origin, not developing the more articulated forms developed by others.

In making comparisons I draw mainly on the interviews and ethnography carried out with Romanian and Moroccan migrants in Italy for the European Science Foundation project "Transnational practices of migrants in Western Europe", coordinated by the Swiss Forum for Migration and population studies ${ }^{1}$.

I have not tried to give a comprehensive review of all the transnational practices among Romanians and Moroccans but have tried to draw out the implications of contrasting situations where particular practices are present or absent. I will first describe transnational practices among Romanian migrants, stressing the absence of many practices found elsewhere. I make some comparisons with Senegalese migrants in Italy, who are much more marked in their transnational orientation, and also with Pentecostal Romanian migrants, who represent an exception to the relatively modest transnationalism of most Romanians. I propose that to understand the differences we need to analyze the structure of social relations among migrants themselves in the place of immigration; this argument is partly derived from an old study of Xhosa rural-urban migration in South Africa by Philip Mayer, which provides a useful analysis of how forms of relationships in a place of arrival may affect ties with "home". More generally, I explore some specifically sociological conditions of the kind of "net work" needed to maintain ties at a distance. I argue that it is the form of life established by

1 This material includes Ambra Formenti's 21 in-depth interviews with Romanian migrants in Italy; Pietro Cingolani's ethnography in Marginea (north-east Romania) and his 15 interviews with migrants to Italy there; 15 interviews carried out with Moroccan migrants in Rome by Mattia Vitiello; articles from the Romanian press collected and summarized by Emilja Drogonearu; demographic data collated by Corrado Bonifazi. Interviewees included men and women of varying ages (20-50) contacted initially via existing contacts.

REMI 2008 (24) 2 pp. 67-90 
migrants (and not, e.g. technology or globalization in the abstract) which is crucial in deciding whether particular practices are present or not. Using the same analytical framework, I discuss the project's material on Moroccans, and make some comparisons with Moroccans in France, to investigate why certain transnational practices found in France are absent in Italy. I then go on to look at circular migration among Romanians, again investigating the specifically sociological dynamics which lead to this pattern. Finally, I draw some implications regarding the concept of transnationalism. I argue that transnational practices are a heterogeneous set of phenomena often unrelated to one another, and linked more to the dynamics of the life cycle than to any overarching historical trend towards globalization.

\section{WEAK TRANSNATIONAL TIES AMONG ROMANIANS IN ITALY: EXCEPTIONS AND COMPARISONS}

First of all, some negative evidence. Ambra Formenti's (2006) interviews, carried out with Romanians in Turin and Ivrea, revealed large numbers of exchanges of the kind which might be included under a broad or loose definition of transnational practices, but absence of the more developed forms. Take, for example, political transnationalism. No interviewee declared interest in affecting politics in Romania via migrants' action. There was generalized cynicism of Romanian interviewees towards politicians and politics in general, but this stimulated no attempt to change the existing elites, or to intervene actively, either as Romanian citizens or more specifically as Romanians living abroad. Discussion about Romanian affairs did not form a significant topic of conversation among migrants in Italy, let alone a focus of action. Few migrants exercise their right to vote at the embassies: at the last general election in 2004, just 4000 persons voted in Italy, out of an estimated total of 150000 having the right to vote $^{2}$. There appear to be few attempts by migrants to make their interests heard in Bucharest. Even individual attempts to keep informed about politics in Romania seem very modest: many migrants watch Romanian news by satellite television, but this seems less common than watching Italian TV news. Sales of newspapers published in Romania are extremely small. There is a widely distributed newspaper for Romanian migrants in Italy, but it is significant that this is heavily focused on the situations and lives of migrants in Italy, giving information about Italian, Romanian and European legislation affecting migrants, measures such as amnesties (before 2007 of course), job information, migrant success stories, and so on - but very little on Romanian politics. We are obviously a long way from the kind of situation where, say, the course of politics in some Caribbean islands may be decided in significant part among circles of migrants in the United States (Glick Schiller et al., 1992), or even from situations where migrants passionately discuss the shape of the polis back home (one may think, for example, of emigrant Italian anarchists or socialists of the early twentieth century, or some Kurdish or Tamil nationalists today).

2 Estimates of Romanian newspapers and Repere romanesti, an on-line service of Romanian associations abroad. 
2.1 Transnational political action seems inconceivable to Romanian migrants also because national associations are not strong. Many interviewees repeated a common self-image or self-stereotype: "We're too individualistic"3. Along with Rome, the Turin area is one of the main destination points for Romanian migrants in Italy. Official figures for regular migrants give over 23000 for the city of Turin alone (2005), and if the surrounding region is included, the figure is over 53000 (Romanians constitute the most numerous nationality in the foreign population in the city - around $30 \%$ of the total foreign population - and in the surrounding region). From a purely numerical point of view, then, the area contains the second most important Romanian "community" in Italy (and one of the largest outside Romania). In addition, since much of the migration in and around Turin has come from a relatively small number of often semi-rural towns and villages, many people have friends and acquaintances in Turin and its hinterland as well as relatives. One might have thought that such clustering would have made the realization of local projects, oriented towards home and local identity, more feasible. Given all these facts (and given a certain amount of encouragement from Italian local authorities who often welcome associations as channels for dialogue with what are seen as "communities"), the level of associational activity is decidedly modest. There is just one really active association in Turin: the other two or three struggle to survive and have great difficulty organizing events or even regular meetings with more than two or three people. Even the main association seems important primarily for the practical information and aid it provides to recent migrants. At Ivrea there is an active association, recently established and involved, for example, in organizing the visit of a Romanian ecclesiastic and a twinning project. However, as in Turin, the existence of the association seems to rest disproportionately on the shoulders of one especially active woman who is the founder and president.

2.2 The same sort of pattern seems to prevail in other areas of life. With the important exception of neo-Protestant Romanians, there do not seem to be genuine examples of collective remittances. When widespread flooding occurred in Romania, the main Romanian association in Turin did organize a scheme asking people to send a donation of one euro by sending an SMS on their mobile phone. However, this is obviously a long way from the more ambitious schemes of collective remittances, aid and intervention in the "home town" described in the literature. Once again, one has no impression of transnationalism in the strong sense of collective mobilization to influence life back home under the leadership of migrants.

3 "Romanians are envious, they don't want to give jobs to others...I think the only thing you can rely on is the family". "Friendship between people from the same place soon fades away...Coming here, we've grown apart [from others coming from the same village or area]. I haven't seen my neighbour [from back home] for a year. In August I invited her round, but she said 'I don't know'." Comments of this type (Formenti 2006), perhaps accompanied by stories of betrayals, debts never paid back, etc. are frequent: the self-image of Romanians as "individualistic" and bad at cooperation wider than the family emerges also from interviews carried out in Bonapace 2006 and Cespi-Fieri 2007. 
2.3 The situation is still more interesting because there is also an important exception among Romanian migrants in Italy: certain types of transnational ties appear much stronger among Romanians who belong to the Pentecostal Church ${ }^{4}$. Pentecostals were pioneers of international migration in Romania in the years after the fall of communism, since they were able to draw on the resources and contacts offered by American and other brethren. International support exists in a way it does not for Orthodox or even Catholic Romanians, and more of a genuine sense of diasporic identity appears to exist: for example, young people seem to have a sense of belonging to networks of established "communities" in several countries of the world. It also appears to be accepted that brethren have an obligation to help each other if possible. This applies in many fields, including help in finding a job. As one interviewee said, "You'll never see a Pentecostal hanging around the square by Porta Nuova" (a square where migrants in Turin looking for work go to wait for offers of casual jobs). In Italy as in Spain, Romanian Pentecostals often own small building firms, and employ mainly co-religionists, thus constituting an essentially closed employment network. The prosperity of these firms may itself owe something to cooperative relations between employers and employees, plus shared values of getting on economically. In any case, if a migrant is accepted as a member of the migrant community he or she will probably find work and leisure contacts intertwined: the social life and organization of leisure time also seems heavily centred around "community" activities connected with the Church and brother Pentecostals.

2.3.1 Given this heavily communal organization of Pentecostal life in Italy, it is interesting that, in contrast to the situation for most Romanians, collective remittances do exist. In Marginea, for example (the small town in north-eastern Romania where Pietro Cingolani (2006) did his fieldwork for our research), a large Pentecostal church has been renovated and decorated via remittances. Projects of benefit to Marginea as a whole have also been financed in the same way, for new facilities have been donated to the local primary school. In other words, there appear to be attempts to intervene in local town life and demonstrate to the local community the benevolent influence of Pentecostalism - initiatives which do not occur among other migrants from Marginea. The fact of living in Italy to a large extent encapsulated in a community of coreligionists mainly from the same town seems to reinforce the idea of being a diaspora, with ties to other nodes of a Pentecostal network, and special ties to the home town.

4 Founded in the early 1920s, the Pentecostal Church in Romania had only relatively small numbers of members and a low-key and controlled (but not illegal) existence during the Communist period, mainly in certain rural areas. It grew rapidly after 1990, when brethren from abroad, especially the USA, provided considerable resources. Most recruitment appears to occur in Romania rather than in countries of emigration. In the 2002 census a little over 330000 declared themselves Pentecostals but the Church claims this is a serious undercount. In some localities - including Marginea, in north east Romania, where Cingolani (2006) carried out ethnography for our research - the division between Pentecostals and Orthodox in terms of life style, social habits, clothing and family forms is fairly sharp. 
2.4 In the interests of understanding the relative lack of many practices among most Romanian migrants, and their presence among Pentecostals, it seems worth referring to a couple of other examples (however different and specific these may be in many respects). A case of migrants in Italy well known for their marked transnational orientation is that of Senegalese belonging to a Murid confraternity of Sufi Islam (cf. the description in this volume by Sall and Salzbrunn of Murid migrants in France). For several decades, Murid migrants from certain areas of Senegal have undertaken a form of circulatory migration involving long and very long stays abroad (in West Africa, in France and, since the 1980s, in Italy), earning money through street trading or by working in factories (for descriptions of migrants in Italy, see Carter, 1991; Schmidt di Friedberg, 1994; Castagnone et al., 2005; Riccio, 2001). Most migrants of these Murid fraternities organize themselves in a strikingly communal way, living together in allmale shared apartments, termed "village houses", delegating particular tasks to particular members (so that, for example, housekeeping and cooking is done by one particular person) and taking many decisions in concert. In many places, migrants have set up a local dahira - the kind of urban association established by rural migrants to cities in Senegal itself - and contribute a significant part of their income to a religious leader and to initiatives of the confraternity in Senegal. Conversation among these men often centres on news from back home. Political conflicts splitting the community affect migrants and vice versa. Gossip and disapproval circulate in the migrant dahira to some extent as in the village or in Louga or Dakar. This membership of recognized communal institutions makes it possible for migrants to be full participants in life back home even though they may have been away physically for years at a time $e^{5}$ It is not surprising in this context that religious and political leaders come from Senegal to visit their followers and potential followers. It is striking that this form of migration - so heavily oriented towards "home" - should have remained relatively constant over several decades: there seems as yet relatively little sign of any progression through various "ages of migration" (Sayad, 1999). It is crucial here that most men (the great majority of the Senegalese migrant population in Italy are men) have wives and children in Senegal. There are few attempts to bring wives or children over: the norm appears to be a stably transnational family, often remaining apart for ten or fifteen years or more. Families are united only in Senegal during a trip home.

2.5 In thinking about the various groups of migrants I have referred to so far, and their varying propensity for the more developed forms of transnationalism, I believe it is worth recalling Philip Mayer's classic comparison between "Red" and "School" Xhosa migrants in the South African city of East London in the 1950s (Mayer, 1962,

5 Not all Senegalese migrants live in village houses and remain so encapsulated within a society of fellow-villagers; the life history information in Castagnone et al. (2005) contains several more individual trajectories. Nonetheless, it is significant that these men have fewer contacts with other Senegalese, more with Italians, make fewer and shorter visits back to Senegal - in this sense fewer transnational ties. The institutional basis of the pattern seems to be the communal life-style of most men. 
$1961)^{6}$. Mayer argued that if we want to understand how "Red" migrants in the urban context maintained such a close attachment to their village of origin, and such involvement in its affairs and conflicts, we need to understand above all the structure of their social lives in East London. Nearly all migrants - whether "Red" or "School" maintained some ties with home, went back periodically, and so on (albeit to differing degrees - like our interviewees). So the difference was not so much one of the strength of individual attachments. The crucial difference between the two groups was that the Red lived among fellow-villagers in the city (and maintained the form of these relations via "traditional" practices of dress), whereas the School had more differentiated networks mixing people originating from different areas. In this way, the School migrants were less subject to control, and less continually stimulated by news, less involved in attempts to intervene in village affairs, to exercise moral judgements on fellow-villagers, and so on. For Red migrants in East London, the sociological basis of the ability and the motivation to maintain active participation in village affairs even while living in the city lay (in considerable part) in the form of social relations maintained in the city.

2.6 I am not, of course, suggesting that all transnational practices are supported by the markedly communal forms of living characteristic of either a Murid dahira or circles of "Red" migrants in 1950s South Africa. These examples, however, seem useful in stimulating reflection on the specifically sociological bases of transnationalism, and in particular in the way the social life of migrants in the place of "immigration" condition attitudes, identity and action - the capacity to maintain a form of participation back "home". Much of the discussion of transnationalism focuses too exclusively on the individual relations migrants have across borders, and on the legal and technological factors which facilitate or restrict such ties (from border legislation to cheap air travel and the Internet). However, the social bases of transnational social units often seem more crucial.

\section{SOCIOLOGICAL PROBLEMS OF MAINTAINING RELATIONSHIPS AT A DISTANCE}

As Smith (2005: 236) has argued, some of the "first wave" of accounts of globalization tended to portray it "as an inexorable structural-economic transformation, operating outside of thought and human practice"; and not a few studies of transnationalism were influenced by this. So now - as Conradson and Latham (2005)

6 "Red" migrants were "traditionalist in their customs and often in their dress and daily habits and attitudes, whereas "School" migrants were more "Westernized" or "urban". Red and School were different to some extent already in their villages of origin (School migrants had indeed more often been to mission-run schools in the countryside). But in the present context, it is Mayer's focus on the effects of social organization in the city which is interesting. The Xhosa migrants to East London did not cross national boundaries (although there were legal restrictions on their movements within South Africa); but I believe the analogy stands nonetheless. 
also argue - it seems important that the study of transnationalism should devote more attention to the practices which maintain communities, organizations and networks in being as viable realities. And this means studying the practices which maintain particular networks and social units as living realities: it cannot just be assumed that, say, two cousins living in different countries will necessarily maintain relations with each other, or provide each other with mutual aid, thus producing a transnational tie. Even less, of course, can it be assumed that two Romanians or Moroccans will necessarily seek each other out. Indeed, nationality is often more a classification significant for outside observers than one which forms a basis for action of actors' themselves (as I have mentioned, our interviews contain numerous reminders that migrants do not always identify with their fellow nationals, and sometimes may even avoid them).

3.1 Certainly, it would be naïve to imagine that the capacity to maintain relationships at a distance varies primarily with technical factors permitting individual contacts at a distance such as telephones. It may be affected by the use of telephones, but the use of telephones is a more sociological affair than the mere technical possibility of telephone communication. Empirical research in France on the effects of geographical moves on telephone contacts show that the existence of the telephone does not solve the problem of distance. In the case of the relationship of friendship, for example, it seems difficult to maintain the tie active after a move. Most contacts with friends - even friends who are described as close emotionally, and with whom telephone calls were frequent before the move - disappear after a few weeks (Mercier, de Gournay and Smoreda, $1999)^{7}$. The technical possibility of telephone contact remains almost unchanged after the move, and even the cost may not be great, but sociological conditions of telephone conversations include having something to say. In general, telephone contacts between individuals are closely correlated with face-to-face contacts (Claisse and Rowe, 1993; Smoreda and Licoppe, 1998; Smoreda and Thomas, 2001), for many phone calls are about matters like arrangements for some meeting, sharing opinions about some faceto-face event, talking about someone else, with whom both interlocutors are in face-toface contact, talking about what that person has done or should do. It seems likely that friendships do not survive geographical separation well because the social context of activities and of shared events and persons who form the basis of the practices making up the relationship tend to fall away ${ }^{8}$. In contrast, contacts between kin - even kin not

7 Mercier et al.'s research was mainly on persons moving within France, so not on international moves. Nonetheless, the general principles of the effects of geographical mobility on telephone contacts would seem applicable also to the international context.

8 Although friendship is often portrayed as a highly individual relationship, in reality it seems to depend heavily on other persons in the background (Eve, 2002). The importance of such third persons in the background comes out clearly at moments when they disappear or appear: so after death of a spouse, divorce, or also with birth of a first child (cf. Bidart, 1997 for a summary of research findings). At these moments when the relationship changes between, for example, A and his/her spouse B, the relationship between friends A and M also changes, because the conversations and exchanges and collective activities which previously formed the substance of the friendship are no longer so important. Even friends who see each other individually are affected in this way by the change in the configuration. 
described as especially close - tend to survive a geographical move much better: Mercier et al. found that calls become less frequent but also longer on average than before the move. Evidently kin have more matters to discuss, and feel more obliged to call. From a configurational point of view, this is understandable, because many of the indirect contacts and exchanges through other relatives remain in place (many of them face-to-face), unaffected by the move of one member of the kin network ${ }^{9}$. Whereas the transactions constituting a friendship relationship (the face-to-face relations with colleagues about whom one complains, the transactions at the school where the children of both friends go) may disappear, this is less true for kin relations. In the case of the kin network, numerous exchanges between individuals other than the two directly involved form the backdrop maintaining the tie. More in general, it seems likely that problems of maintaining a relationship at a distance are not primarily about maintaining individual ties but rather the general configuration which keeps ties active.

3.2 It is therefore misleading to consider transnational practices independently of this general network context. Even a transnational practice as elementary as making a phone call to someone in another country requires the "work" of many people in the background (cf. Becker, 1982 and his insistence on the hidden "work" which goes towards the production of any particular social product ${ }^{10}$ ). Barry Wellman (1985) talks aptly of "net work" needed to keep networks active. Some of this is done consciously e.g. when someone acts as "kin keeper" maintaining contacts, remembering birthdays, organizing festivities and meetings. Migrants' trips home are other important occasions for renewing the network ${ }^{11}$. Ruba Salih (2003) provides good descriptions of the amount of time - and worry - devoted by the Moroccan women she interviewed to preparations for trips home, selecting suitable gifts for individual people back home. The quantity of such gifts can be gauged by the fact that many Moroccan migrants return home by car rather than plane (even though the latter would be cheaper) in order to be able to take more gifts.

9 As Margaret Grieco (1987) has pointed out, indirect ties are fundamental in explaining why kin networks are often so effective and reliable in conveying aid. A often helps B not because of any great love but because not helping is liable to cause problems with $\mathrm{C}$ and intervention from D.

10 Becker's work on "art worlds" shows that the production of an art work is by no means the work of one individual alone, painting, composing, etc. in isolation. People like publishers, critics, gallery-owners, other artists, friends, performers and many others have a fundamental role in the actual creation of the work in question. Becker clearly intends his work to have general sociological implications and takes art partly as an illustration of the fruitfulness of describing the entourage of persons who make a particular form of action possible. I cite it here to stress that transactional practices, too, may sometimes be represented in too individualistic a way, stressing the technical conditions of transnationalism but not the sociological ones.

11 It is important in this context that trips home for many migrants are made almost impossible by the fact of being undocumented. Economic difficulties also limit visits home, which are often costly because of the gifts as well as because of the lost income caused by an extended visit. In other words, not all migrants are able to keep up these practices which have an important function in keeping a kin network genuinely active. 
However, much maintenance of the network linking a migrant with home takes place via activities in the "immigration country". The structure of social relations constructed by migrants in the place of migration is important in this sense. If socialists, anti-communists, nationalists, supporters of one faction or another succeed in making circles in migration where conversation, plans, quarrels with other migrants are all centred around these, then participation in the life of events back home is maintained. Membership of these social circles in the country of migration gives meaning to passionately reading news from home. The everyday practices of life in the country of immigration make ties with the country of exile alive. Similarly, living in a "village house", or centring social life around activities with Pentecostal "brethren" from the same town, may continue participation in the affairs of a community geographically distant.

In contrast, the structure of everyday social relations and activities of most Moroccans and Romanians in Italy supports little more than the maintenance of the kin network (perhaps including fictive kin: godparents: Cingolani, 2006). As I have described, most Romanians and Moroccans live in Italy in networks restricted primarily to socializing with family members and a few friends ${ }^{12}$. A Sunday in Italy spent with one's sisters and brothers-in-law may help keep alive ties with kin still in Romania, discussing concerns about an elderly relative, making plans as to what to do, etc., but probably does not maintain other relations back home. The gifts presented by Moroccan migrants during a visit home may define and renew a wider range of relationships than those of Romanians' August visits. And if social relations are centred heavily on other Moroccans this may reinforce affective nostalgia and attachment to "home". But forms of action in Italy sustaining action and conversation connected with political participation in a community back home or in a political nation are rare.

3.3 When transnational practices depend almost exclusively on kin ties, the rhythms of such practices obviously evolve with family life events. For example, among Romanian migrants, remittances are substantial and regular when parents are living in Italy and separated from their children in Romania, but fall abruptly to merely occasional gifts if the children moved to Italy (CESPI-FIERI, 2007). So money sent back by migrants to their own parents, for example, was regular and substantial when the latter were looking after the grandchildren, but not otherwise. As will be seen below, patterns of circular mobility also seem to vary according to the evolution of family ties in the life course.

12 Many interviews contain statements like the following: "When we have some free time, we spend it in the family - we eat together or have a coffee or a grappa. My brothers and sisters are at ..., we go to them or they come here". Cf. similar statements in Bonapace et al., 2006; CESPI-FIERI, 2007. 


\section{MOROCCANS IN ITALY AND FRANCE: CONTRASTING PATTERNS}

As I have indicated, many similarities with Romanians are in evidence when we look at the transnational practices of Moroccan migrants in Italy. Once again, we can see the combination of weak associational ties, lack of collective (as against individual) remittances ${ }^{13}$, general pessimism regarding the possibility of political change and a scarcity of attempts to intervene in political life in the home country. For many Moroccans, as for many Romanians, religious centres are important bases for social life, as well as religious practice, places where one meets co-religionists and conationals one might not otherwise meet so often. In this sense, they certainly increase the density of contacts with co-nationals, contributing to the construction of something a little nearer to a "community", and to reinforcement of identity, and thus indirectly contribute to the maintenance of attachment to 'home'. However, as I have indicated, manifestations of anything wider than kin-maintained practices remain slight. Although Ruba Salih's (2003) book on Moroccan women in Italy bears the word transnationalism in its title, the everyday practices described are overwhelmingly either practices maintaining kin ties across frontiers (via telephone calls, remittances, visits), or practices (e.g. eating Moroccan cuisine, decoration of the home using Moroccan elements in combination with others in a syncretic whole) which are part of the homemaking of a Moroccan immigrant in Italy as much as a transmigrant fundamentally different from immigrants of the past.

4.1 Since a number of transnational practices among Moroccans in Italy are absent which are prominent in France (Lacroix 2005; Lacroix, Sall, Salzbrunn in this volume), Belgium (Martiniello and Bousetta in this volume) and elsewhere, it is worth exploring the differences briefly. In particular, collective remittances and development initiatives are more common in France and political transnationalism more developed in Belgium.

4.1.1 At first sight, the relatively recent nature of mass migration to Italy might be thought to explain the difference. Schuster (2005) has suggested that this (along with the need for many migrants to move around Italy in search of work) explains the relatively slight development of associations among migrants in Italy; and, as I have stressed, strong associations, or informal community organization, are essential for many of the more developed transnational practices. On this hypothesis, we might imagine that, with the passage of time, and greater job stability and economic security, more collective initiatives might emerge. In this way, we might imagine, in time,

13 As with Romanians, the exceptions to this are minor - small amounts of money being raised for a national disaster such as an earthquake. This kind of activity significantly implies no lasting link between a specific group of migrants coming from one particular village or region and a specific group of migrants from that area. In this sense it seems very different from the kind of initiative reported by Lacroix, Sall and Saltzbrunn in this issue: e.g. providing electricity or water to one's own village.

Perhaps the most important type of aid given by Moroccan migrants in Italy is paying to have the body of a dead person flown back to their family in Morocco (Vitiello 2006). 
seeing, for example, the kind of co-development project described by Lacroix and others, funding the provision of water or electricity, a school or library to a village, or also attempts to influence the political scene in Morocco.

4.1.2 However, on the whole, the evidence does not seem to support this hypothesis that the difference is merely one of time. The importance of the time factor is certainly not evident in the case of Senegalese migrants: Senegalese migrants have been highly involved in strong forms of transnational activity throughout their history of migration in Italy (from the late 1970s and early ' 80 s). Not only today but also in the past, all the transnational practices described in France (see Lacroix, Sall, Salzbrunn in this volume) existed in Italy - from frequent visits of religious leaders to collective remittances to political campaigning for Senegalese politicians (Carter 1991; Castagnone et al., 2005). Sri Lankan migrants also seem to have established very active associations at an early stage in the migration process (see, e.g. Palidda and Consoli, 2006). In contrast, Moroccans in Italy do not seem to have developed the early forms of collective remittances which were developed in France even thirty or more years ago, at a similar stage in the migration process. Lacroix (2005) cites several cases in which even in the first years of mass migration from a particular village, collective remittances contributed to projects - most typically building a mosque in the village, but sometimes a pump or irrigation system. These early initiatives are not only significant in themselves but also because they indicate a general orientation towards village concerns which was a key element mobilized by later initiatives involving associations and NGOs, convincing the latter to contribute. It seems to have been these spontaneous initiatives which inspired the idea of migrant development associations in the first place, and already existing initiatives of this kind made it easy to raise the money for the quota of funding coming out of migrants' pockets which these projects require ${ }^{14}$.

4.1.3 It is this element of village-centred mobilization, therefore, which seems to be lacking in the case of Moroccans in Italy. It is not immediately clear why this should be different in Italy. However, patterns may be quite localized. The cases Lacroix (2005) documents are fairly localized (mainly mountain villages in Berber-speaking villages in the South, and only secondarily in the Rif). One might ask whether there are large numbers of Moroccan migrants in France who do not have these kinds of village ties, and whether their transnational ties are different. In any case, with regard to the lack of such initiatives in Italy, it may be relevant that so many migrants come from large cities. Although data on the particular location in Morocco where a migrant comes from are not very reliable because respondents may cite a nearby town they think Italians may recognize, large proportions of Moroccan migrants cite cities - especially Casablanca - as the place they come from. Of course, this does not necessarily mean the people in question have no ties with a village "of origin", for many families living

14 As Lacroix (2005) describes, migrants' development organizations require that a group of migrants themselves contribute a part of the cost of a project such as providing electricity or running water to a village (say $40 \%$ of the total), while village members provide free labour. Other funding agencies, NGOs or government agencies, then provide the rest of the funding. 
in the outskirts of Casablanca may come from the countryside. But the reply does suggest that these migrants do not instantly identify with a village. In the context of interaction among Moroccans in Turin, Capello (2003: 82) refers to migrants associating together on the basis of "the same neighbourhood in Casablanca or the same road in Khouribga" (the medium-sized town which is the other main sendingpoint for migrants to Turin and some other Italian towns) - not a village.

4.2 It would be interesting to investigate different attitudes to collective initiatives in a village also in the context of patterns of family reunion. Family reunion may have been more rapid in Italy in the 1990s and the 2000s than it was in France in the 1960s or '70s, where many men lived for many years in hostels, hôtels meublés or chambres de bonnes. Although numbers of Moroccan men in Italy have experienced this classic pattern of men living alone (the kind of pattern described by Sayad and many others in the 1960s and '70s), many more formed families in Italy after a few years. This can be seen in the changing sex balance of the Moroccan population in Italy: whereas in 1992 (the first year reasonably reliable statistics are available), males made up $91 \%$ of the adult population ${ }^{15}$, by 2004 this was down to $69 \%$, and is rapidly falling ${ }^{16}$. It would be interesting to know (in the Moroccan case but also more in general) more about how family reunion affects decisions regarding spending and saving, and orientation towards life in the home country.

4.3 Other forms of transnational practices more prominent among Moroccans and their descendants in France than in Italy have been the creation of highly educated and politically-involved figures - who are not numerous among Moroccan migrants in Italy. Lacroix, Sall and Salzbrunn refer to the importance in France of political activists who were forced to leave Morocco in the wake of repression in the 1960s. This little migration - no doubt going to France because of pre-existing personal and institutional links - was important in founding associations which are still important today, or which gave birth to others. Lacroix and his colleagues also refer to Moroccan and Moroccan-origin students belonging to an association of students of grandes écoles which organizes development initiatives in Morocco. There is no equivalent of this in Italy either, because Italian universities currently have few Moroccan or Moroccanorigin students (a mere 978 students of Moroccan nationality were registered in all Italian universities combined in 2007/2008: MIUR, 2008). Italian universities currently attract few students from abroad in general (the children of national elites are rarely sent to Italy to study), and the numbers of second generation Moroccan youth attending university is still extremely low (a sign of the continuing economic insecurity of many Moroccan families as well as the fact that a second generation educated in Italy is only now reaching university age in significant numbers).

15 The figures are the Ministry of the Interior data for permits to stay (permesso di soggiorno), which are usually given only to adults (children being included on their parents' permit).

16 In Piedmont, for example, Moroccans were 58\% male overall in 2006 (including children), and still more equally distributed in many individual towns. Cf. Osservatorio regionale sull'immigrazione, www.piemonteimmigrazione.it. 
4.3.1 In other words, some transnational initiatives, especially of the more politically-oriented type, but also initiatives intended to modernize a country in general, rather than being directed to a particular village, depend on the existence of educated elites. In this context, the American literature on transnationalism may represent a somewhat special case, not applicable everywhere. Caribbean and Central American elites have always studied in American colleges and had multiple links with American institutions, while for their part, United States institutions have often been interested in providing migrants and exiles with resources for intervening in a region not unjustly referred to as "America's back yard". These kinds of links producing elite migrants and contacts in the USA are not necessarily present everywhere. A country like France with significant links dating back to colonialism has more than Italy.

\section{BUSINESS ACTIVITIES AND THE NEED FOR EMBEDDED- NESS}

I have already referred to the relatively modest levels of migrants' economic activities linking up Morocco and Romania with Italy. I do not want to deny the existence of some initiatives, simply to note their small scale in comparison with business activity developed by migrants within Italy. Cingolani and Piperno (2005) and Cingolani (2006) cite individual cases of Romanian migrants managing small businesses e.g. transporting migrants, their remittances and packages, and importing or exporting building materials to take advantage of price differences between Romania and Italy. Vitiello (2006), AMERM 2005, Stocchiero (1999) and others describe cases of Moroccan migrants starting up small businesses in Morocco with government incentives, importing food products. Yet the scale of such initiatives seems small compared to the size of the two communities. To give just one example, at the time of the research there was just one self-employed migrant importing Romanian food specialities in Piedmont: hardly impressive in a region with over 53000 Romanians. But above all, the numbers of initiatives seem small when compared to the large amount of entrepreneurial activity Moroccan and Romanian migrants put into business based within the confines of Italy. In 2006 there were 24000 small firms registered by Moroccans in Italy and 12600 registered by Romanians (Grandi 2006). Such firms form a significant proportion of total firms in some sectors: at a local level, a recent study in Turin (FIERI/Camera di Commercio di Torino 2008) found $7.2 \%$ of all the city's firms in the distribution sector were owned by Moroccans; while $15.1 \%$ of all the firms in the building sector were owned by Romanians. Yet our interviews and qualitative studies by Castagnone (2008), Gasparetti (2008) and Camera di Commercio di Torino (2005) found only fragmentary and occasional evidence of transnational ties in terms of suppliers, travel for business or investment in the home country. Moroccan grocers may import fresh mint and coriander but for most of their supplies rely on wholesalers in Italy or France. The proportion whose business depends on transnational ties is certainly not comparable with, say, Portes, Guarnizo and Landolt's Salvadoran, Colombian and Dominican entrepreneurs in the USA: in that sample, 58\% of all those in self-employment were engaged in transnational activities (Portes et al., 1999: 
Table 1$)^{17}$. These firms were mainly in sectors bi-national or multinational by definition, such as couriers, travel agents and importers, with a clientele primarily of co-nationals. In contrast, the small firms of Moroccans and Romanians in Italy are mainly in services and building predominantly oriented towards the Italian market, which they find more profitable and reliable.

5.1 It is true that alongside the more stable forms of self-employment and small business registered with the Chamber of Commerce, there is also widespread petty trading which often does involve transnational ties. When driving back for a holiday, a good many Moroccans use the occasion not only to take numerous presents but also various items which are cheaper in Italy than in Morocco (perhaps including the car itself), and which can thus be sold to acquaintances (Semi, 2004; Saleh, 2003). For most people, however, this is an occasional supplement to their income. It is true that a fair number of young men do undertake such trips more regularly, transporting cars, sometimes combining stolen goods with those bought second-hand. However, as among young men in the Marseille area (Peraldi, 2001, 2002), this kind of activity is usually described by the men themselves as a fall-back activity undertaken because of lack of ability to find a satisfactory job in Italy. Only rarely does it seem to be conceived of as a career and a proper business to be developed in a long-term perspective (see interviews in Semi, 2004 and Capello, 2003 for profiles of the young men concerned). In general, therefore, it seems more plausible to consider the majority of these entrepreneurs as undertaking an activity which is characteristic of a certain stage in the life-cycle.

5.2 Projects of cross-national enterprise seem to run into classic problems of trust (Gambetta, 1988). In spite of the advantages of exploiting borders, in many ways the entrepreneurial function seems one which relies intrinsically on the intensive development of local relations. It is significant in this context that several Romanian interviewees complain that the most fruitful opportunities in Romania are taken by people who have remained in the country and developed their political contacts, and grasped opportunities at the right time; and migrants feel marginalized from these networks (cf. also Cingolani and Piperno, 2005). Being present at just the right moment, cultivating one's political ties, having excellent knowledge of suitable opportunities, can all be more important than the opportunities provided by frontiers. More in general, it seems useful to think of the importance of local relations - with customers, with other firms from which one can learn, with sources of information - as crucial to business success. It seems relevant to recall here work on "industrial districts" and the importance this gives social relations in a specific local area (Bagnasco, 1988). Accounts which imagine large-scale expansion of transnational enterprise tend to forget this kind of question regarding the background of social relations surrounding entrepreneurial activities.

17 A "transnational entrepreneur" was defined by Portes et al. as someone self-employed, with or without employees, who went back at least twice a year for business, and who declared in the research interview that links with the home country and/or other countries were crucial for the success of the business. The criterion was not, therefore, very demanding; nonetheless few Romanian or Moroccan businesses would meet it. 
5.2.1 It is significant in this context that the incentives for investment in Morocco provided by the government (eager to attract the resources of migrants and channel them into investment projects: AMERM 2005) often seem to be met with scepticism. Those with money to spare prefer to invest in business in Italy, and take-up for the government schemes has been limited in Italy (Stocchiero, 1999; Vitiello, 2006; AMERM et al. 2005). The difficulty of really knowing how trustworthy business partners are, and of overseeing activities from abroad, evidently seems discouraging.

5.2.2 Many Moroccans and Romanians, like innumerable migrants in the past, do have projects for starting up some sort of small business back home - a shop, car repair business, small restaurant, etc. However, these plans (which often remain just plans, as Formenti (2006) notes) are not so much the kind of dynamic investment which development agencies dream of, oriented towards expansion, but rather part of a strategy of retirement ensuring a minimal personal income. In this kind of context, a shop or restaurant (perhaps functioning just a few months of the year) may fit in to a strategy which provides a small income, adequate when combined with other sources (perhaps even including migration for part of the year).

\section{CIRCULAR MIGRATION: FAMILY STRATEGIES AND FLEXIBLE LABOUR}

A form of clearly transnational existence which is common among our Romanian interviewees is circular migration. Although not particularly new, it is important because of its frequency and the role it plays in sustaining rural life. Research collecting data in Romania has documented how widespread the pattern is, at least in rural areas and small towns (Lazaroiu et al., 2001; Diminescu, 2003; Diminescu and Lazaroiu 2002; Sandu 2000, 2005; Potot, 2003). This is an important pattern which may exist elsewhere, but may well be missed by research methodologies collecting data only in arrival countries (where circular migrants are difficult to interview and often not in official figures). Our interviews in Marginea in north-east Romania (Cingolani, 2006) found temporary migration to be common both among people who had stable jobs (especially in the public sector, e.g. during the summer holidays of schools), and among those who combined several small sources of income and were happy to include migratory work in this overall strategy - without any intention of "emigrating".

6.1 How can circular migration work? Sometimes it relies on fitting together the needs of Italian employers and Romanian migrants. A significant part of the seasonal workforce in some sectors of agriculture (fruit-picking, wine-harvesting, taking cattle or sheep to their summer pastures) in some local areas of Italy is now composed of Romanians undertaking a "working holiday". However, in other cases, employers are themselves migrants. Thus a Romanian with his own micro-enterprise in the building trade may telephone from Italy to an acquaintance back home, saying he has need of an extra hand. In other words, one competitive advantage of such small migrant firms is their ability to draw on a transnational supplementary workforce in a very flexible way 
- just calling workers for a few weeks when needed. As well as cost, there are also questions of having known and reliable workers, as one builder explained: "I needed workers. I chose them among people from the village. This suited me, because I need a team of people who can work together, who know each other and who I can trust. And it suits them, because they arrive [in Italy] knowing there's a job for them" (Formenti, 2006).

Not only builders but also Romanian women working as carers of old people often may "call" a relative or friend back home. In this case, it is the desire for a break from work, or the need to deal with a family crisis back in Romania, which often leads a worker to ring up and ask for a substitute for a month or two (CESPI-FIERI 2005).

6.1.1 The system has certainly been facilitated by changes in border regulations. In 2002, as part of preparations for Romania's entry into the EU, Italy abolished the requirement for a visa. Romanian citizens could therefore enter legally for tourist reasons for up to three months with a minimum of bureaucracy. In theory of course, they could not work, but the costs of entry were reduced considerably (with some exceptions). Since January 2007, of course, movement has been easier still. Other studies of changes in European regulation also suggest changes in legislation may have had similar effects. At an earlier stage of European integration, it has been suggested (Reyneri, 1979; Pugliese, 2002) that introducing free circulation of labour in the EEC encouraged Italian migrants to adopt strategies going back and forth rather than settling stably in Germany. It will be interesting to see if entry of Romania into the EU has effects in further encouraging movements of this kind ${ }^{18}$.

6.2 However, border rules are not the only issue, for the Romanian research cited above, showing how widespread the pattern is, predates the 2002 relaxation of controls. There are also sociological determinants in this kind of temporary migration which seems clearly oriented towards preserving the viability of life in the village/town. Cingolani's interviews in Marginea bring out a clear pattern in the age and life-cycle characteristics of circular migrants: the strategy of short trips is one adopted by people who have firm family ties and are in their forties and fifties, whereas it is much less common among younger people ${ }^{19}$. It is clear, moreover, that migrants coordinate their migrations with those of their spouse and children, according to a clear family logic: "For the last six years I've worked for a farmer near Asti, who has a lot of vines. I usually go in the spring, when he has to prune the vines, then my wife goes in the summer to look after the farmer's children, then I go again when there's the wine harvest. In the winter we both stay in Romania. Alternating like this, there's always someone to look after the house: when my wife's away I look after the children, wash the clothes, cook. The only disadvantage is that doing things in this way I've saved less than I would have if I had worked without any interruptions" (Cingolani, 2006).

18 The issue is interesting from several points of view: it has been suggested that this kind of back-and-forth strategy pursued by Italians was one possible reason for relatively poor results of the children of Italians in German schools, as compared to several other secondgeneration groups.

19 Of course short trips are not always an intended strategy. Some young people may return from Italy after just a few months simply because they do not manage to find work. 
6.2.1 In semi-rural towns like Marginea, extra money gained by a month or two's work abroad provides a useful supplement in income - enabling one to pay a daughter's university fees, buy a new television, fridge or other equipment for the home, rebuild part of the house, etc. So a wife/mother may willingly substitute a sister or cousin in Italy while the latter takes a month's holiday from caring for an elderly person. Likewise, a husband/father may be glad to spend a couple of months on a building site in Turin. The rationality of this kind of strategy depends on the objective not so much of maximising income but of maximising standard of living ${ }^{20}$ (probably higher in Romania for many migrants than in Italy). Some people with stable conjugal relationships ${ }^{21}$ seem to want to maintain a way of life in places like Marginea, feeling their own life is better and less stressful than it would be if they moved permanently to Italy. For some older couples with adult children living abroad (perhaps in two or three different locations), it is important to maintain a firm base for migrant children returning for holidays. The popularity and duration of this pattern of circulatory mobility in Romania (and perhaps elsewhere) may thus depend on life-cycle and family factors as much as on changes in border regulations. It would be interesting, for example, to know whether the pattern is characteristic mainly of certain types of semirural towns (the focus of Cingolani's ethnography but also of the large-scale survey exploited by Sandu, Lazaroiu, Diminescu and others), or whether it exists also in cities.

6.3 The potential for this kind of migration is obviously limited by employers' (and other workers') demand for short term labour. It is significant here that all the examples we documented were in the sectors of agriculture, building and domestic/care work - precisely the sectors where similar seasonal or short-term employment of patterns existed in earlier centuries. This suggests that this kind of pattern may not expand much outside these areas.

6.4 Another interesting aspect is a certain level of institutional toleration of circular migration among public institutions and employers in Romania. Evidently, in a context where migration is a recognized strategy, schools, hospitals and employers may be willing to tolerate absences of staff, fearing that not to do so may induce them to leave permanently.

\section{TOP-DOWN TRANSNATIONALISM AS A CAREER OPPOR- TUNITY}

Most of the practices discovered by our research are examples of "bottom up" transnationalism. However, there are obviously also more "top down" forms of transnationalism, where it is a formal organization which provides the framework

20 On the concept of standard of living, the most penetrating statement (highly relevant for understanding the logic of migrants' decisions) remains Sen (1987).

21 Interviewees with migrants often bring out the multiple connections between migration decisions and events in family history like separation, divorce, and deaths and illnesses of close family members. This is a fundamental factor structuring the capacity to maintain a particular social field, and therefore also a transnational social field. 
coordinating and making possible social action in two or more countries. International organizations in Italy naturally employ Romanians and Moroccans along with other nationalities, and thus provide the organizational support for careers in more than one country - career structures where cultivating links with one's home country may be a means of occupational mobility. If we had undertaken research in the North East of Italy, no doubt we would have found Romanian technicians working for Italian firms (in textiles and other industries) coordinating work in the two countries, transferring skills, etc. (Stocchiero, 2002), and small numbers of Moroccans act as representatives of Italian firms in Morocco (cf. Castagnone 2008 for one example).

7.1 Among the educated Moroccan migrants who made up Mattia Vitiello's interviewees in Rome, there were several people whose links with Morocco depended in part on this sort of organizational framework. In general, the occupational opportunities for skilled migrants in Italy are notoriously slight. A considerable number of posts are reserved either for Italian citizens or for people who have an Italian diploma (procedures for obtaining recognition of foreign diplomas are laborious). Above all, a lengthy period of waiting is often necessary before finding a post, even for Italians; such long waits may not be feasible for migrants. Among the few posts which in contrast are available to foreigners are those where knowledge of a language, contacts with a particular immigrant "community", or knowledge of local conditions in a country of emigration are considered crucial. For this reason many educated migrants in Italy have sought jobs in this little niche. Many have become mediatori culturali, translating and mediating between public agencies (social work agencies, courts, local councils, etc.) and migrants, undertaking various forms of community action; others have found jobs in international development agencies. Specialization in providing information about Morocco and Moroccans has led a couple of Vitiello's interviewees to increase their ties with their country of origin. Several interviewees had personal trajectories which in many ways led away from maintaining close links with Morocco e.g. a break with the family of origin over marrying an Italian man, failure to find conationals of similar status in Italy, so forming friendship groups formed mainly of Italians. Yet these people who previously had few ties with Morocco or with other Moroccan migrants were led for work reasons to multiply their ties with Moroccans in Italy and with Morocco. In other words, both contacts with "the Moroccan community" in Italy, and ties with Morocco and Moroccan institutions can be seen, in a way, as a product of integration trajectory in Italy, given the few niches effectively open in the Italian labour market.

7.1.1 For example, one woman worked in an Italian association promoting women's rights, where she specialized in Moroccans, another in a development agency working in Morocco among other places. This work led to trips to Morocco (where of course, friends and family were also visited), work with various Moroccan governmental bodies and local groups, and with institutions for "Moroccans abroad" like the Hassan II Foundation. These contacts, in turn, stimulated interest among some of these interviewees regarding politics in Morocco. The women interviewed were interested in spreading awareness of the new, less "traditionalist" family $1 \mathrm{law}^{22}$, and even hoped to

22 With support from the new king and various ministers, a new family law was introduced in 2004, after three years of consultations and work in a commission. The new law has been 
exert a little influence on discussion of related issues in Morocco itself. In this sense, they could be seen as transmigrants acting politically (albeit in a very modest way). However, we should note that their activity clearly grew out of the organization, not vice versa: the personal ties of these women with co-nationals prior to taking a job were slight (they looked down a little on fellow Moroccans in Italy as less educated) and it is only now that they have reinforced such contacts. The dynamic is essentially an organizational one, or that of the Italian labour market, quite different from that of most of the other phenomena considered here.

\section{CONCLUSION}

As several recent commentaries on the concept of transnationalism have argued, it seems necessary to devote more attention to the specific practices which sustain transnational ties. I have stressed that it is essential to consider not just the direct practices (such as international telephone calls or sending of remittances) but also the organization of life among migrants in their everyday lives in places like Turin and Marginea which gives a sense to the calls and remittances. It is this background "net work" which is necessary to sustain social fields of any kind, whether geographically clustered or scattered. Most of the transnational practices we documented among Romanians and Moroccans in Italy were supported and given meaning almost exclusively by kin. For this reason, they were affected by the rhythms of development of kin regrouping and life-cycles: deaths, divorce, separation, regrouping of the most significant members of the family in one single country - all these events may radically affect transnational practices. So a family which is transnational at one moment can cease to be so a few years or months later.

Underlying much of the interest in transnationalism is a sort of implicit philosophy of history - the idea that transnational practices are signs of globalization and communication technology "dissolving boundaries" and making social processes within the borders of nations less central. In this implicit view, all instances of action spanning national boundaries can appear manifestations of one fundamental social trend, necessarily "increasing" even if not altogether new. However it may be more appropriate not to see one coherent object of study, indicating "the future" but a heterogeneous series of practices with different dynamics. Empirical investigation of the diffusion of transnational practices (including the negative cases) shows they are very patchy. And comparisons between situations where they exist and where they do not, suggest not so much any overarching tendency towards increase, but rather fluctuation during the life cycle and according to the structure of social relations among migrants in one place (the town "of immigration"). The sociological conditions for maintaining social action at a distance remain considerable; insufficient attention has been devoted to these.

widely seen as a milestone and provides a much more egalitarian framework for women regarding matters such as responsibility for the family, custody and divorce, as well as rights for children. 


\section{References}

AMERM, EL SUR, PUNTO.SUD, COOPI (2005) Il migrante marocchino come agente di sviluppo e di innovazione nelle comunità d origine, Milan, Exodus.

BAGNASCO Arnaldo (1988) La costruzione sociale del mercato, Bologna, Il Mulino.

BECKER Howard (1982) Art Worlds, Berkeley, University of California Press.

BIDART Claire (1997) L'amitié. Un lien social, Paris, La découverte.

BONAPACE William, EVE Michael, PERINO Maria (2006) Una società che cambia. Immigrazione e convivenza nella provincia di Asti, Asti, ISRAT.

CAMERA DI COMMERCIO DI TORINO (2005) Imprenditori stranieri in provincia di Torino, Turin, Camera di Commercio.

CAPELLO Carlo (2003) Torino, Maghreb. La costruzione di identità trasversali tra i migranti marocchini, in Sacchi, P., Viazzo, P., Più di un Sud. Studi antropologici sull' immigrazione a Torino, Milano, Angeli.

CARTER Donald (1991) La formazione di una dahira senegalese a Torino, in IRES Piemonte, Uguali e diversi, Torino, IRES.

CASTAGNONE Eleonora (2008) Porta Palazzo plurale. Il caso del commercio marocchino, in Fieri/Camera di Commercio di Torino, L'immigrazione che intraprende. Nuovi attori economici in provincia di Torino, Torino, Camera di Commercio di Torino.

CASTAGNONE Eleonora, CIAFALONI, Francesco, DONINI, Elisabetta, GUASCO, D., LANZARDO, L. (2005) Vai e vieni: esperienze di migrazione e lavoro di senegalesi tra Louga e Torino, Milan, Angeli.

CESPI-FIERI (2007) Madri migranti. Le migrazioni di cura dalla Romania e dall' Ucraina in Italia, Roma, Cespi Working Paper, 34.

CINGOLANI Pietro (2006) Migrants' Transnational Practices in Western Europe. Romanians in Italy, Research report for European Science Foundation project "Transnational practices of migrants in Western Europe".

CINGOLANI Pietro, PIPERNO, Flavia (2005) Il prossimo anno a casa. Radicamento, rientro e percorsi traslocali: il caso delle reti migratorie Marginea-Torino e Focsani-Roma, Roma, Cespi Working Paper.

CLAISSE Gérard, ROWE F. (1993) Téléphone, communications et sociabilité : des pratiques résidentielles différenciés, Sociétés contemporaines, 14-15.

CONRADSON D., LATHAM A. (2005) Transnational urbanism: attending to everyday practices and mobilities, Journal of Ethnic and Migration Studies, 31 (2) March.

DE VAULT Marjorie (1991) Feeding the Family. The social organization of caring as gendered work, Chicago, University of Chicago Press.

DIMINESCU Dana (ed.) (2003) Visibles mais peu nombreux. Les circulations migratoires roumaines, Paris, MSH.

DIMINESCU D., LAZAROIU S. (2002), Circulatory migration of Romanians, Bucharest, IOM.

DROGOREANU Emilia (2006) Review of articles in Romanian local and national press discussing migrants in Italy, Turin, Fieri.

EVE Michael (1999) Les réseaux sociaux des jeunes en décohabitaion, research report, Paris, Cnet.

EVE Michael (2002) "Is friendship a sociological topic?” Archives européennes de sociologie, 3, 2002.

FAIST Thomas (1999) Transnationalism in international migration: implications for the study of citizenship and culture, Working Paper Series, Transnationalism Communities Programme, Oxford.

FORMENTI Ambra (2006) Pratiche transnazionali dei migranti rumeni a Torino, research report, Turin, Fieri. 
FIERI/Camera di Commercio di Torino (2008), L'immigrazione che intraprende. Nuovi attori economici in provincia di Torino, Turin, Camera di Commercio di Torino.

GAMBETTA Diego (1988) Trust. Making and breaking cooperative relations, Oxford, Blackwell.

GASPARETTI Feodora (2008) I percorsi dell'imprenditoria edile a Torino: strategie individuali tra emancipazione e subordinazione, in Fieri/Camera di Commercio di Torino, L'immigrazione che intraprende. Nuovi attori economici in provincia di Torino, Torino, Camera di Commercio di Torino.

GLICK SCHILLER N., BASCH L., SZANTON BLANC C. (eds.) (1992) Towards Transnational Perspectives on Migration, New York Academy of Sciences.

GLICK SCHILLER N., BASCH L., SZANTON BLANC C. (1995) From immigrant to transmigrant: theorizing transnational migration, Anthropological Quarterly, 68.

GRANDE Enrico (2006) Diffusione e grado di consolidamento dell'imprenditoria straniera in Italia, in Immigrazione. Dossier Statistico 2006, Rome, Caritas/Migrantes.

GRIECO Margaret (1987) Keeping it in the Family, London, Tavistock.

ITZIGSOHN J., DORE CABRAL C., HERNANDEZ MEDINA E., VAZQUEZ O. (1999) Mapping Dominican transnationalism: narrow and broad transnational practices, Ethnic and Racial Studies, vol 22, no.2, March.

KISTIVO Peter (2001) Theorizing transnational immigration: a critical review of current efforts, Ethnic and Racial Studies, vol. 24, no.4, July.

LACROIX Thomas (2003) Espace transnational et territoires: les réseaux marocains du développement, thèse de doctorat, Poitiers.

LAZAROIU S. et al. eds. (2001) Circulatory migration of Romanians from rural areas and small towns, Bucharest, IOM.

MAYER Philip (1961) Tribesmen or Townsmen, Oxford, Oxford University Press.

MAYER Philip (1962) Migrancy and the study of towns, American Anthropologist, vol. 64.

MERCIER Pierre-Alain, DE GOURNAY Chantal, SMOREDA Zbigniew (2002) Si loin, si proches. Liens et communications à l'épreuve du déménagement, Réseaux, 115.

MIUR Osservatorio Studenti (2008), website of the Italian Ministry of Education, www.miur.it.

PALIDDA Rita, CONSOLI Teresa (2006) L'associazionismo degli immigrati tra solidarietà e integrazione, in Decimo, F., Sciortino, G., eds. Reti Migranti, Bologna, Il Mulino.

PERALDI Michel (2001) Cabas et containers. Activités marchandes informelles et réseaux migrants transfrontaliers, Paris, Maisonneuve et Larose.

PERALDI Michel (2002) La fin des nourias? Réseaux migrants dans les économies marchandes en Méditerranée, Paris, Maisonneuve et Larose.

POTOT Swanie (2003), Circulation et réseaux de migrants roumains: une contribution à l'étude de nouvelles mobilités en Europe, Thèse de doctorat, Université de Nice-Sophia Antipolis.

PUGLIESE Enrico (2002) L'Italia tra migrazioni internazionali e migrazioni interne, Bologna, Il Mulino.

REYNERI Emilio (1979) La catena migratoria : il ruolo dell'emigrazione nel mercato del lavoro di arrivo e di esodo, Bologna, Il Mulino.

RICCIO Bruno (2001) Disaggregating the transnational community. Senegalese migrants on the coast of Emilia-Romagna, Working Paper, Transnational Communities Programme, Oxford, COMPAS.

PORTES Alejandro, GUARNIZO Luis, LANDOLT Patricia (1999) The study of transnationalism: pitfalls and promise of an emergent research field, Ethnic and Racial Studies, vol 22, no.2, March.

SALIH Ruba (2003) Gender in transnationalism. Home, longing and belonging among Moroccan migrant women, Abingdon, Routledge.

SANDU Dumitru (2000) "Circulatory Migration as Life Strategy", Sociologie Romaneasca, no. 2 , pp. 65- 92 . 
SANDU Dumitru (2005) "Emerging Transnational Migration from Romanian Villages", Current Sociology, vol. 53, no. 4, pp. 555-582.

SAYAD Abdelmalek (1999) La double absence, Paris, Seuil.

SCHMIDT DI FRIEDBERG Ottavia (1994) Islam, solidarietà e lavoro. I Murid senegalesi in Italia, Turin, Fondazione Giovanni Agnelli.

SCHUSTER Liza (2005) The continuing mobility of migrants in Italy: shifting between places and statuses, Journal of Ethnic and Migration Studies, vol. 31, no. 4, July.

SEMI Giovanni (2004) Le multiculturalisme quotidien: Porta Palazzo entre commerce et conflit, Thèse de troisième cycle, EHESS/Università di Torino.

SEMI Giovanni (2006) Il ritorno dell'economia di bazar. Attività commerciali marocchine a Porta Palazzo, Torino, in Decimo, F., Sciortino, G, eds. Reti Migranti, Bologna, Il Mulino.

SEN Amartya (1987) The Standard of Living (The Tanner Lectures, 1985, Clare Hall, Cambridge, ed. G. Hawthorn), Cambridge, Cambridge University Press.

SMITH Michael (2005) Transnational urbanism revisited, Journal of Ethnic and Migration Studies, vol. 31, no. 2, March.

SMOREDA Zbigniew, LICOPPE Christian (1998) Effets du cycle de vie et des réseaux de sociabilité sur la téléphonie, Issy-les-Molyneaux, CNET.

SMOREDA Zbigniew, THOMAS Frank (2001) Social networks and residential ICT adoption and use, paper presented at Eurescom Summit, Heidelberg 12-15 November, 2001.

STOCCHIERO Andrea (1999) Circuiti economici e circuiti migratory nel Mediterraneo, Roma, Cespi.

STOCCHIERO Andrea (2002) Migration flows and small and medium-sized enterprise internationalization between Romania and the Italian Veneto Region, Rome, Cespi.

VERTOVEC Steven (1999) Conceiving and researching transnationalism, Ethnic and Racial Studies, vol. 22, no. 2.

VITIELLO Mattia (2006) Migrants' transnational practices: the case of the Moroccan community in Rome, research report for the European Science Foundation project on "Migrants' transnational practices in Western Europe".

WELLMAN Barry (1985) Domestic work, paid work and net work in S. Duck, D. Perlman, eds., Understanding Personal Relationships, London, Sage. 


\title{
Bases sociologiques des pratiques transnationales en Italie
}

\author{
Michael EVE
}

Les différents groupes de migrants montrent des niveaux de transnationalisme très variables. Si on refuse le «nationalisme méthodologique » il semble nécessaire d'enquêter aussi sur des cas «négatifs » qui devraient faire la lumière sur les conditions nécessaires pour maintenir des unités stables à travers les frontières. L'article s'appuie sur des entretiens avec des migrants roumains et marocains en Italie pour explorer les raisons des niveaux modestes du transnationalisme politique et économique. On compare avec d'autres groupes où certaines pratiques sont plus développées. L'article soutient qu'il faut être plus attentif aux racines spécifiquement sociologiques des pratiques. On discute la logique qui soutient le modèle de mobilité circulaire des Roumains qui travaillent dans le bâtiment, l'agriculture et l'aide à domicile.

\section{Some sociological Bases of transnational Practices in Italy}

\section{Michael EVE}

Transnational practices are of very variable intensity among different groupings of migrants. If we reject an automatic "methodological nationalism" it seems worth asking why some migrants develop relatively weak forms of transnational ties: negative as well as strikingly positive cases seem worth investigating and above all comparing, in order to throw light on sociological roots of transnational practices. This essay draws on interviews and ethnography with Romanians and Moroccans in Italy to investigate the reasons for modest levels of economic and political transnationalism generally found (with some interesting exceptions). Comparison is made with cases of other groups where practices are more developed. It is argued that more attention should be given to the social practices necessary to maintain transnational units stably. Some instances are explored where transnational ties and activities are - or are not maintained (circulatory labour migration of Romanians between Turin and north-east Romania, transnational business activity).

\section{Algunas raíces sociológicas de prácticas transnacionales en Italia}

\section{Michael EVE}

Prácticas transnacionales son de intensidad muy variable entre las agrupaciones diferentes de migrantes. Si rechazamos un automático "nacionalismo metodológico" parece mereciendo la petición por qué algunas migrantes desarrollan formas relativamente débiles de corbatas transnacionales: casos negativos así como casos positivos parecen la investigación para esclarecer las raíces sociológicas de prácticas transnacionales. Este ensayo utiliza entrevistas y etnografía con Rumanos y Marroquíes en Italia para investigar los motivos para los niveles modestos de transnationalism económico y político generalmente encontrado (con algunas excepciones interesantes). La comparación es hecha con los casos de otros grupos donde las prácticas son más desarrolladas. Es argumentado que deberían dar a más atención a las prácticas sociales necesarias de mantener unidades transnacionales establemente. Algunos casos son explorados donde corbatas transnacionales y actividades son - o no son - mantenidos (la migración circulatoria de trabajo de Rumanos entre Turín y nordeste Rumania, la actividad económica transnacional). 